\title{
Changing the Turkish Constitution: An Institutionalist and Collective Action Perspective
}

\author{
Türkiye Anayasasını Değiştirmek: Kurumsalcı ve Kolektif Eylem Perspektifi
}

\author{
Hayrettin Özler ${ }^{1} \odot$, Alim Yılmaz $^{2} \odot$, Didem Geylani $^{3} \odot$
}

\begin{abstract}
Understanding change and/or resistance to change is critical in studying institutions. We argue in this paper that the supply of expressible alternatives to the status quo, as well as the provision of incentives for political parties and other socio-political formations to participate in collective action for institutional change, are essential. These can be described as "ideational monopoly" of specific actors or "supreme legitimacy" of established institutions, but the latter can be described as "institutional handicaps" in a problematic way. According to a survey of the literature, institutional transformation follows a largely isomorphic pattern for the most part. In Turkey, it is undeniable that the European Union associated Turkish objectives have been the primary engine of institutional transformation in the country for a long time. Some historical turning moments in Europe-Turkey ties, as well as the associated actions of governments and public opinion towards the Turkish constitution, imply that there is almost a visible correlation between constitutional change and EU-Turkey relations, at least in the short term. As a result of this affinity, we have argued in favor of isomorphic approach as the most successful means of bringing about structural change.
\end{abstract}

\section{Keywords}

Turkish Constitution, EU, Institutionalism, Collective Action, Isomorphic strategies

Öz

Kurumları incelerken değişimi ve/veya değişime karşı direnci anlamak çok önemlidir. Bu çalışmada, statükoya yönelik ifade edilebilir alternatiflerin sağlanmasının yanı sıra, siyasi partilerin ve diğer sosyo-politik oluşumların kurumsal değişim için, ortak eylemde bulunmalarının elzem olduğu savunulmuştur. Bunlar, belirli aktörlerin "düşünsel tekeli" veya yerleşik kurumların "yüksek meşruiyeti" olarak tanımlanabilir, ancak ikincisi sorunlu bir şekilde "kurumsal engeller" olarak anlaşılmaktadır. Literatürde, kurumsal dönüşüm büyük ölçüde eşbiçimli model olarak sunulmaktadır. Türkiye'de Avrupa Birliği vizyonunun uzun süredir kurumsal dönüşümün ana dinamiği olduğu yadsınamaz. Avrupa-Türkiye ilişkilerindeki tarihsel dönüm noktaları, hükümetlerin ve kamuoyunun Türk anayasasına yönelik değişim talepleri ile AB-Türkiye ilişkileri arasında görünür bir ilişki olduğu aşikardır. Bu yakınlığın bir sonucu olarak, yapısal değişimi sağlamanın en başarılı yolu olarak izomorfik yaklaşımın etkili olduğu iddia edilmektedir.

Anahtar Kelimeler

Türk Anayasası, AB, Kurumsalcılık, Kolektif Eylem, İzomorfik Stratejiler

1 Hayrettin Özler (Prof. Dr.), Dumlupınar University, Faculty of Economics and Administrative Sciences, Public Administration, Kütahya, Turkey. E-mail: hayrettin.ozler@dpu.edu.tr ORCID: 0000-0001-7056-4061

2 Corresponding Author: Alim Yılmaz (Prof. Dr.), Istanbul Medeniyet University, Faculty of Political Sciences, Political Science and Public Administration, Istanbul, Turkey.E-mail: alimyilmaz@gmail.com ORCID: 0000-0002-2658-0109

3 Didem Geylani (Ress. Asst.), Van Yüzüncü Yıl University, Faculty of Economics and Administrative Sciences, Department of Public Administration, Van, Turkey. E-mail: didemgeylani@gmail.com ORCID: 0000-0002-4865-1975

To cite this article: Ozler, H., Yilmaz, A., \& Geylani, D. (2021). Changing the Turkish Constitution: An Institutionalist and Collective Action Perspective. SiYASAL: Journal of Political Sciences, 30(2), 193-205.

http://doi.org/10.26650/siyasal.2021.30.984112 


\section{Introduction: The Main Question}

Institutions are more than formal-legal arrangements; they are the means of enforcing dominant values and social cohesion, the ways for survival of desired interactions and interdependencies within a polity and thus the main obstacles for change in status quo. To understand change and/or the resistance to change stands paramount in studying institutions beyond description. We argue here that institutional change depends on the supply of expressible alternatives to status quo and of incentives for political parties and other socio-political formations to engage in collective action for institutional change. The former can be named problematically as "ideational monopoly" of certain actors or "supreme legitimacy" of established institutions while the latter can be named as "institutional handicaps". The first problem implies that change requires beliefs, understandings, and knowledge which are critical against the material and ideational legitimacy of existing institutions and favorable toward the possibility of new forms of prospective institutions. The second problem implies that change incurs costs due to existing institutional inhibitions and necessitates incentives for collective action to change institutions. A review of literature revealed that institutional change follows mostly an isomorphic pattern. It is obvious that the Europe (not necessarily the European Union) associated Turkish ambitions has been the main driver for institutional change in Turkey. Some historical turning points in Europe-Turkey relations and concomitant actions of governments and public opinion regarding Turkish constitution suggest the existence of some form of correlation between constitutional change an $<\mathrm{d}$ EU-Turkey relations. This affinity has led us argue in favor of isomorphic strategies as the most effective means for institutional change. Yet we conclude that the availability and success of isomorphic change requires some in-home dynamics (social, economic, and political) to couple with.

\section{Institutional Explanations for Change}

Institutionalism differs from behaviorism in that it defines institutions as social systems that structure social interactions rather than as simple patterns of behavior. When there is a clashing duality between change and permanence, institutions evolve. Institutionalism is defined as the view of institutions as independent or given variables that decide how things will be done. Institutions, on the other hand, have a binary dimension. For example, they can be used for two different forms of rationalization: instrumental and ceremonial (or empirical and normative, see Rothstein, 1996). On the basis of exoteric knowledge, instrumental rationalization refers to a dynamic process of adaptation to satisfy changing needs, interests, and other environmental necessities in a dynamic context. Ceremonial rationalization, on the other hand, means the continuity and longevity of habits, beliefs, symbols, and routines founded on esoteric knowledge that are the results of past processes and circumstances, and as such, are never fully in agreement with the requirements of the current time.

Even though many people are aware of this two-sided nature of institutions, the difference between utilitarian and ceremonial functions is primarily Weblenian. In the Weblenian meaning, the term "instrumental" refers to performance that is founded on notions such as causal reasoning, purposive thoughts, and cause and effect, as well as other concepts. The phrase "ceremonial" refers to authority, social standing, custom, 
tradition, and precedent (Klein and Miller, 1996). In other words, institutions are not solely logical structures. They are a combination of both. They are partially created on purpose in order to improve the efficiency, interests, and optimality of interactions, for example, by increasing the number of encounters. Moreover, they emerge unintentionally because people have limited rationality (both in terms of knowledge processing and knowing), are "chosen" by accidental or path dependent events and are a combination of conflicting or collaborating sources of social power, whether moral, economic, or military in nature.

\section{Instrumentalist Arguments}

Institutions as instruments serve the purpose of reducing transaction costs, providing incentives for collective or coordinated action, reducing uncertainty, and meeting environmental challenges. According to Williamson organizations and institutions are essential for mutual social transactions as well as constrained conflict. Transaction costs are higher where there is lack or slack of institutionalization, yet contradictorily there is neither transaction cost and nor a patterned change where there is no institution at all (like in a perfect market) Williamson, 1975). Thus, institutions can provide transacting actors (like states, citizens, organizations) with competitive advantage because they rule a certain power-relationships between constituents (Rhodes, 1995:46). By creating institutions, the actors will be able to create moral commitments, predictability, and information accuracy. Yet as routines, habits and self-justifying rules serving to incumbent interests, institutions will increase transaction costs for collective action and thus hindering institutional change.

According to an Olsonian argument, institutions are not supported because of the collective goods (such as legitimacy) they provide to their constituency, but rather because they provide "selective incentives" to the actors, regardless of whether they contribute to the provision of the collective good. It becomes more expensive to take collective action for institutional change as mandatory institutions (and actors) prefer to promote prior acquisitions and the status quo, a state of being we prefer to call as institutional handicap. When it comes to understanding the politics of change in Turkey, it is far more appropriate to concentrate on organized political parties than on constituency expectations. Contrary to this, local support for political parties has been considered because it has an almost direct impact on the party composition following national elections or on the views of political parties following referendums. North (1990), for example, and other representatives of the school of economic institutionalism argue that institutions evolve in response to the will to reduce uncertainty. This straightforward understanding implies that ineffectiveness of institutions will not necessarily result in change because, right or wrong, effective, or ineffective, institutions supply information that strategic players can utilize to make informed decisions. In the pursuit of economic, political, and social transactions, institutions in the face of uncertainty provide a fundamental structure and background for organization and change to take root and flourish. On the general process of change, North believes that organizations - economic, political, and social - behave as agents, and that they adopt new institutions or technologies when they believe that doing so will enable them to better their competitive position (North, 1990 and 2005). Economic institutionalism also suggests that institutions do not change by themselves. Institutional change involves actors (within and outside the incumbent institutions) who facilitate the destabilization, deinstitutionalization and finally re-institutionalization 
of existing institutions. That means institutions are not always uniform. Instead, they inhabit different sub-cultures, values and non-conformist individuals who can initiate change in an institution. Organizations being an open system recruit new members, acquire knowledge, and are influenced by change in other organizations that form the larger institutional and organizational system of universe. Within this universe, larger and stronger units are less likely to change as they can dominate and condition their institutional environment. Unless there is a depression, crisis, an exogenous intervention, and/or some other change incentives, institutions will remain intact as latent interests are weak, dispersed and in large number, which make it harder to unite against small number of powerful interests who are advantageous in uniting their resources to prevent change and reform (see, Olson, 1982).

Another institutional argument (isomorphism) put forward is by the DiMaggio and Powell (1983) who argued that most organizations (or units like states) change not to be different but to be alike to others which face similar environmental challenges. The change is not about being different but about being fit for the environment or about being similar to those who are more likely to survive or more likely to change the environmental conditions. This is because of four (but not exhaustive) factors: (1) interaction among units and actors; (2) institutional structures of domination and patterns of coalition; (3) increase in their information load with which units and actors have to contend; and (4) the development of a mutual awareness among actors towards a common enterprise make disparate organizations more similar to one another. Eventually, "organizations may change their goals or develop new practices...but in the long run; organizational actors making rational decisions construct around themselves an environment that constrains their ability to change further in later years" (DiMaggio and Powell, 1983:148).

According to DiMaggio and Powell (1983), there are two types of isomorphism: competitive and institutional. Since they are analytical rather than empirical distinctions, they can both be observed in the same environment. This is because the diversity of units is dependent on the diversity (tolerance) of the environment. The former suggests that in a free environment, where competition, niche change, and fitness are all important features, isomorphism is passionate in a competitive setting. Competition for resources and supporters exists between organizations. In the latter, groups compete more for political power and legitimacy than they do during the former. Three types of institutional isomorphic change are identified by the authors: coercive isomorphism, which arises from political influence and legitimacy concerns; mimetic isomorphism, which arises from standard responses to uncertainty, and normative isomorphism, which is associated with the development of expertise. On the other side, mimetic isomorphism is a result of the uncertainty and ambiguity of the environment, in which firms, rather than innovate, choose the strategy of imitating and modeling other organizations that appear more legitimate or successful than their own. As a final point, because of professionalization, normative isomorphic change takes place, which involves a communal effort to define the conditions and techniques of interactions. Some of the variables that contribute to normative isomorphism include the advancement of education, the professionalization of workers, socialization, and effective communication. Notably, these structurizations of interaction also result in the structurization of incentives supplied by central organizations, as is the case with the EU, which constrain the environment's entry and exit options. 


\section{Ceremonial or Normative Arguments}

Without changing norms or ceremonial-normative aspects of institutions, institutional change cannot be expected to happen. Institutions, according to the old and normative institutionalism, are to protect a collective good and increase the legitimacy of the procedures, not the interests of the stronger or embedded actors. Stinchcombe (1997: 8) argues that people believe that institutions can provide right kind of answers to problems, and they embody a value that the people also accept. Thus, in the old tradition an institution's defining characteristics is legitimacy.

According to Stinchcombe, market (economic) institution has the logic of appropriateness that is the rules and accepted practices supplemented with the logic of consequentiality (profit). Legitimate market competition allows the destruction of older institutions and their legitimacy through accompanying depression. Without belief in the legitimacy and the value of capitalist institutions, “... we cannot explain why capitalism can first legitimate the horse-and-buggy industry and then legitimate the automobile industry that destroys it, without changing the basic institutions of capitalism" (Stinchcombe, 1997:17). Depressions increase the potential for challenging the legitimacy and value of existing institutions by new and more competitive ones. The old institutionalism defends the view that institutions are not simple formalities or procedural rules; instead, they are means to reason and good sense which are the values in themselves. For instance, secret ballot and confidentiality is essential in voting not because they are values but because they are crucial to assure honest opinions which come with the immunity of the voter. "... [T] he reasons for having things institutionalized and ritualized is that they matter" (Stinchcombe, 1997:10).

More social choice research concedes that the legitimacy of institutions is dependent on the degree to which their values are widely accepted. The status quo presumes worth since "there is no way to discern if a proposed move away from the status quo is desired unless it is agreed upon" (Buchanan, 2004:139). In the absence of clear solutions, when institutions cease to give consensus, public support for new or alternative institutions grows, such as in the case of social movements or reformers who mobilize popular support. In other words, performers follow socially established, publicly known, anticipated, and accepted conventions and practices when acting. Society and state are composed of people who obey rules with specific cultural linkages, including shared codes of meaning and methods of reasoning, and who see themselves as members of a distinct group. Social contact and experience shape identities and rules, which themselves both foundational and regulatory at the same time.

Therefore, change is rarely a planned event, but rather the product of the confluence of several opportunities, values, learning, reflexes, and choices within institution and its environment. For instance, the greater the degree of disjuncture between the institutional values and institutional behaviors and between the values of surrounding society and the behavior of the institution, the more likely will change be (Peters, 1999:33-34). In other words, unless there are emerging values or an exogenously injected values which are presumed to count for more than the existing ones there will be no change. Change may be result of agreement through an internal exchange game or internal disagreement which leads to the intervention of an external player by means of some form of isomorphism. 
Part of understanding political development and institutional change is understanding which ideas win (or, in fact, which ideas are in the arena to begin with), why, and with what consequences for whom. The important point is not only where ideas come from or how they cohere or collide but also how they come to be prominent, important, and powerful, even determinative in shaping political behavior and defining political rationality (Lieberman, 2002:700).

\section{Institutional Explanations for Resistance to Constitutional Reform}

Institutions survive on their own merits because of the sunken costs invested in them, their information value and the risk of uncertainty that change will bring in the future, the cost of collective action required to engage in the change process, their perceived sacredness (Rothstein, 1996) because they have a long history (not chosen), they are ours and part of collective identity, and so on. The representatives of institutionalist economists, Douglas North (2005:50), for example, admit that "while formal institutions can be changed by fiat, informal institutions evolve in ways that are still far from completely understood and therefore are not typically amenable to deliberate human manipulation". A radical institutionalist perspective suggests that institutions possess a reality of their own, a reality that confronts the individual as "an external and coercive fact" (See, Berger and Luckman, 1967). According to Berger and Luchman (1967:136) the more abstract the institutions are the less likely they are to be modified in accordance with pragmatic exigencies. To change them requires conflict between reality defining experts and practitioners. Experts with privileges, hypocrisy and grandiose pretentions claim to know the ultimate significance of existing institutions.

An institution's very essence is one of permanence. An established institution is less subject to moral evaluation than an emergent institution is (Suchman, 1995:584). Some, for example Olson, would suggest that established institutions are usually protected by small, homogenous, well-organized, powerful interest groups while the primary actors of reform are like a large, ill-organized and latent group (Olson, 1965). Institutions are generally initiated and invested in by powerful elite with vested interests and legitimating ideology which are functional for status quo. Therefore, change in institutions comes when these self-enforcing mechanisms fail or when an external critical incident or actor causes a juncture of discontinuity (Pierson, 2000; Mahoney, 2000; Horton, 2006:33). Otherwise, as Hirschman's (1991) jeopardy thesis suggests, every reform proposal will be perceived as endangering previous accomplishments which are believed to be the results of existing institutions. Established interest and pressure groups would resist change since they can easily challenge the legitimacy, credibility, and success of new entrants. An institution relies on a substantive determination, will, and choice of parties who also staff the institution. Institutions may lower transaction costs of interactions yet existing institutions as status quo and our dependence on them raise the transaction cost of adopting new institutions. The reason why the political authority alone cannot achieve democratic reforms is that when they acquire power, they are no longer outsiders and thus they do not want to lose the power and authorities they have gained. Once a rule has been established as an institution, it will not be easily modified due to its information and coordination importance. The existence of an alternative institution does not mean that changing the old institution would be quick or easy, as that would require overcoming the cost of transactions. 
Recognition of this fact reveals a crucial distinction between constitutional design and constitutional reform. In constitutional design, where there are no effective preexisting rules, all that is relevant is the choice between the rule that generates one set of outcomes and the rule that generates an alternative set. The rule that gives rise to the preferred set of outcomes is to be preferred. But when there is the question of changing an existing rule, as is the case in constitutional reform, the rule that generates the most preferred set of outcomes carte blanche is not necessarily dominant (Brennan and Buchanan, 1985:11).

Even when there are opposing views, there are also counterarguments. It is important to first remember that organizations and institutions should not be viewed as hindrances to progress or a static condition in which nothing can be done to improve the state of affairs. The second way in which institutions can help people reduce the difficulties associated with free-riding and prisoner's dilemma issues that are encountered in nearly all collective action situations that foster change is through the means of revolution, reform, law and order, or a favored policy outcome. We used the Commons' and Ayres' perspectives of reasonableness as well as Weblen's serviceability notion, and they have implications for the entirety of which include the concepts of equity, workability, individual and collective welfare (weblen's serviceability) (Klein and Miller, 1996:267). These perspectives conceptualize institutional pragmatism as generating answers to perceived difficulties by accepting ideas as provisional and contextual rather than dogmatic or absolute truths. Institution is an ever-changing state, one that continues to grow. Weir (1995) and Thelen (2003) explain that this evolutionary change happens through bounded innovation (or incremental change) which then leads to layering new systems on top of existing structures (Horton, 2006:33). This sort of institutional evolution is known as a punctuated equilibrium, as proposed by Krasner (1984). Finally, according to Judge (2003:501), institutionalization itself means a process of institutional change without an end point and without a common process.

In contrast, non-institutionalized and non-uniform organizations and governments are not more likely to change than those that are more institutionalized and more uniform. Even if organizations with more fluid structures struggle to implement change in a way that's both orderly and predictable, this may be because of powerful interests and collusive groups that gain from chaotic conditions or believe that maintaining order is more expensive than allowing disorder. We can see disorder manifest in communities that lack enforceable laws and institutions, as well as in cultures whose norms and institutions have not been formed by consensus. The instability and lack of strong coalition governments in Turkey in the early 2000s thwarted implementation of reforms there. In nations where elections are common, governments have difficulty implementing reform ideas because it is difficult to hold them accountable or oblige them to accept responsibility for their party's initiatives and policies. Populist and particularistic policies were common in Turkish politics until the early 2000s, as is shown in the policies implemented by regimes aiming to win reelection. Turkey has powerful incentives to delay making reforms, particularly if the reforms benefit not only them but also a massive and amorphous public.

In Europe, there has been a constant admiration for Turkey's struggle to build a country and nation since the early twentieth century, even if it was practical and short-lived. The country's economic, social, and political institutions have been extensively reformed to ensure compatibility with the EU. One significant contributor to the progress of reforms 
in Turkey has been the EU, which has played a crucial role as a standard, facilitator, and even a driving force in Turkey. One of the most effective ways primary change agents use to get secondary groups to resist a new institution is to show its mismatch with established reference points. The EU was successful as long as its goals remained unchanged. The main reasons that support our argument in favor of mimetic change are the instability of competitive politics to make lasting constitutional arrangements and lack of consensual support for constitutional change in Turkey. Thus, European based aspirations and the outsider effect of European demands fill this void.

\section{The Anatomy of Resistance to Constitutional Change in Turkish Polity}

The rules and regulations governing political action are often constitutionally or legally rooted (Drewry, 1996:201). The lack of grassroots support in the Turkish constitution formation process has resulted in fragile constitutions (Özipek, 2012:158). While the state of law is under additional global and local pressures to relax the established rules and conventions that restrict individual rights and democratic political participation in "non-democratic" countries, these pressures exist within an existing framework of constrictions. In some less democratic countries, constitutional laws and institutions have been primarily established to define elitist rules and methods for building a nation state.

Since the early 20th century, Turkey's state and nation-building endeavors have focused on Europe, which was seen as the greatest success. However, they did it pragmatically and dynamically. Beginning in 1987, several political, social, and economic reforms were undertaken in Turkey to make the country suitable for European Union membership. The EU has been seen as a role model, a facilitator, and even a force that causes Turkey to embrace reforms that would have been difficult to implement internally due to coordination/information problems and relative financial gains that are acceptable to different political factions. Facts demonstrating an organization's incompatibility with established points of reference are often one of the key strategies that change agents employ to rally secondary groups to combat emerging institutions (Henisz and Zelner, 2005). If the EU aspirations are kept alive, then this reference point is available.

Several historical records may show the power of European aspirations in the progress to institutional change in Turkey. Since an Association Agreement was signed in 1964, and the country was admitted to the Customs Union in 1995, Turkey has maintained a questionable cooperation with the European Union. Since December 1999, Turkey has been recognized as a candidate country for EU membership, and negotiations commenced in October 2005. Significant setbacks have occurred due to Turkey's negotiations with the EU practically came to a halt in June 2018. Many fields such as security, energy, and transportation and trade policies have been collaborating on conversation and collaboration, according to the report of the commission for 2019.

Turkey invalidated the 1964 decree which had frozen the assets of the Greek minority since 1963. Also, a legislative body, the Turkish Grand National Assembly, authorized the individual petition of Turkish people to the ECHR, and for supervision of the human rights advances, a Parliamentary Committee was established. After signing and ratifying the European and UN treaties against torture in 1988, Turkey became the first Muslimmajority country to become a party to those treaties. Furthermore, the 200 capital 
punishment verdicts that had been pending review by the National Assembly have not been accepted, thus they cannot be carried out. When new reforms were adopted in 1991, the new reforms allowed publications to use Kurdish language, cancelled Articles 141, 142, and 163 of the Penal Code, and converted the death sentences to 20 years and life sentences to 15 years. A ministry was established to deal particularly with human rights matters in the same year, and this permission was extended to human rights organizations the next year. Even yet, the country has had to deal with the issue of balancing improved human rights with efforts to combat terrorism. An illustration of this paradox can be seen in the Anti-Terror Law issued at the same time. Following the Summit of the Eight in Helsinki in the year 1999, the reform process was reaccelerated, which led to Turkey becoming a candidate country. Despite severe barriers to implementation, significant human rights and freedom changes have occurred since the Helsinki Summit in 2001. Top-down implementation is opposed by those who say it lacks societal dynamics. We disagree, however, because the changes have not been implemented completely, and there are always other spheres of influence opened by statutory entities that are not controlled.

Despite the vote held in September 2010 which will make things easier for a constitutional reform or a new constitution, the political and societal debate on constitutional reform continues. There was a widespread public and political consensus that to facilitate greater democracy, the Turkish Constitution must be modified to provide the freedoms that align with EU standards. As it is widely accepted, the constitution was prepared during the military coup of 1980 and supported by a small group of law academics, many of whom were officers in the coup. A total of four amendments to the 1982 Constitution had been approved through popular vote, two of which occurred under the AKP administration after the 2002 elections (Esen and Gümüşcüoğlu, 2017). Following the September 2010 referendum, Turkish political parties, the Constitutional Court, and the High Council of Judges and Prosecutors were reformed, as was the position of an Ombudsman, which was also utilized, while the freedom to use other languages was further and trade union rights were enhanced.

Despite retaining various regulations that restrict free speech through criminal charges and investigations, Turkey protected the freedom of expression. The provisions 301, 318, 288, and 216 of the new Penal Code have been employed in many investigations and prosecutions of people working in the civil society and the public arena, including political figures on both the left and the right. Only in rare instances, and criminal punishment of peaceful individuals for expressing their freedom of expression is a violation of the European Convention on Human Rights. And it's important to note that attention must be paid not just to the formal institutions, as many free-thinking writers face the risk of violence and even death at the hands of the rising extreme right youth and nationalist factions. Even while there are several assumptions of defectors within security services and the public that may safeguard the executers and perpetrators of these atrocities, there are still serious uncertainties if this assumption holds true. In 2006, the number of people convicted for stating their point of view increased over the previous year. In 2007, prosecutions increased further. In the last five years, the Ministry of Justice claims that there have been approximately 6,775 people tried under Paragraph 159 and Article 301. There were 745 convicted people. In the large majority of cases, the charges levied 
against them under the Criminal Code, as well as the other important articles outlined above, are violations of Article 301, which makes insulting "Turkishness", the Turkish Republic, and the governmental organs and institutions a criminal offense.

A shift in form, style, conditions, and ideas for all occurs because of globalization and Europeanization. While the shift is moving in one direction, it does not happen at the same rate because a few scholars, such as Yansamayan (2016), believe that there is a reverse and forward movement to be defined as Europeanization/de-Europeanization (following 2006). On the other hand, there are other scholars, such as Cebeci (2016), who assert that a dynamic and dialectic Foucauldian counter-conduct analysis is required to comprehend the fluctuations in institutional change in Turkey, and the role of the EU. Despite AKP governmental efforts to favor their own constituencies while engaging in institutional and constitutional reforms favored by the EU, the AKP nevertheless pushed through with reforms in EU-prioritized sectors.

The argument of many scholars, as summarized in a review by Inglehart and Baker (2000), is that freedom of expression renders authoritarian regimes inefficient and costly to operate and produces intra-elite disagreement. The Human Progress Approach says that when economic development has increased individual resources, people have moved away from survival principles and are focusing on their personal values and expressions. On the other hand, it also concedes that progress along a simple, straight path is not always applicable. Developmental states have developed an affluent society, but not always a democracy. Because the government of Turkey was backed by public and electoral support, they were able to continue to curtail some of the essential rights and freedoms while keeping most of the rights and freedoms intact.

A liberal position holds that institutions should strive to do good rather than bad- to help and enhance people - rather than hurt and hinder. A society needs an institutional framework capable of constant absorption of change in order to keep developing. It is a common saying that "as society evolves, new needs arise, new constituents wield power, and new aspects of the political, economic, social, and other realms are required to keep up with the changing times." This is another way of saying that legal-political systems need to be able to deal with the demands for greater freedoms while also maintaining the continuity of the current system. There is a need for an institutional structure that can successfully cope with the transition and accompanying challenges, as well as maintaining a continuing life for itself.

Many different elements and processes all working together make for complex social, political, and economic transformation. As of 2018, the presidential system's coming into full effect has reshaped the presidency and the states' administrations. Concerns were expressed by opponents in the national and European parliament, as well as in civil society and the media, all in protest of the seeming reduction in civil society's multiplicity of views. When the pathways taken by different societies are as unique as this, it will not be possible for different societies to have the same characteristics. Meanwhile, there are several parallels between practically all societies. Anomie or dysfunctions within the social system are responsible for the changes in the system. Institutional infrastructure must be replenished in order to correct dysfunctions. As far as development and modification of ideas and mental models are concerned, the media, colleges, civil society, 
and good governance mechanisms are the key ways to accomplish so because they are in place prior to the concept's creation and evolution. Thus, learning and the change of ideas are closely linked because they enable participants to promote change in society and government. The channels they form are good for expressing and emphasizing the desire for change. There are many different current institutions, such as the rule of law, that lay the groundwork for future institutional activities. However, the opinions and beliefs of the general people are formative in shaping government policy decisions. While ideas can be converted into institutional choices and change if structural actors and interests see these ideas acceptable or adoptable, it is important to note that it takes time for structural actors and interests to consider ideas as being viable or acceptable. With governments that do not respect people's free expression and political engagement, carrying out projects of change is difficult in societies that are defined by centralized government, leader-dictated political parties, oligopolistic interest groups, and state-dependent civil society.

\section{Concluding Remarks}

Institutionalism holds that leaders who lead the effort to institute change are generally not strong or organized enough to gain entry to the limited decision-making agenda. They aim to amass a broad array of disparate, disorganized interests in order to be able to grab the attention of policy makers. They use propaganda strategies such as manufacturing believable threats in the event that things stay the same, creating joint action incentives that cater to certain interests, and highlighting the benefits of the change they are advocating. Bringing the perimeter to the center therefore indicates a move toward the center. The periphery groups (e.g. municipalities, silent majorities or minorities) are likely to support changes since they can see the benefits to themselves. In Rowan (1982), the authors found that the policies that states, regulatory agencies, and interest groups adopt and keep reflect a balance or consensus between the state and local governments. In contrast to central government institutions, in which government agents aim to integrate growing groups into "the state" apparatus to secure their agreement in support of the status quo or top-down reform efforts, periphery governments see it as important to enlarge "the polity" instead. Generally, the focus of resistance from the bottom to the top is not aimed at altering the essence of the reforms, but rather aimed at decreasing the power and influence of central governments or powerful factions.

Institutionalism emphasizes that institutions are in a constant state of flux, yet fluctuation is also an institutional concept. For an example of institutional transformation, consider nation-state creation or modernization. While there will always be a route to nation-state building and modernization, things don't happen overnight. Even if the shift is completely spontaneous and multifarious, individuals bring order to it by arranging it into understandable patterns. Unless we notice a discernible pattern or trend, we cannot sense any "change in progress." Changing or destroying an institution without recognizing how it was constructed is nearly impossible. The process of changing things is quite similar to the method of building them. Even amid an apparently chaotic shift, one can still see the route and pattern of change that was formed over time.

At the beginning of this paper, we distinguished between the two aspects of institutions, referring to the dichotomy of instrumental/ceremonial. Although the ceremonial aspects 
oppose the message of new knowledge and change, they do, in a manner, facilitate it. Experiential facts (the proper performance of instrumental action) necessitate shifts in cognition and emotion (ceremonially empowered behavior) (Klein and Miller, 1996, s.274). For a majority or influential minority of institutional constituents to adopt instrumentally indicated behavior and revise ceremonially warranted concepts and rituals, they must surmount the natural tendencies towards superstition, ignorance, conservatism, dogmatism, and so on. Pretention, by definition, takes the place of reflective thinking. The greater society or other elite/power centers should be convinced by social movements and reformers, adherent for change, by developing arguments that use reasoning, instead of emotion, to achieve their goal. They will also require diverse and plentiful evidence to weaken the legitimacy and legacy of the repressive institutions, as an organization that is widely accepted is seen as having greater legitimacy and a more significant legacy. From an institutionalist point of view, changing any meaning is an isomorphism since evaluating alternatives involves considering their conformance with the institutional context, rather than judging them on their own merits. the reason Turkish institutions are in a constant state of change is due to the push to embrace new requirements in the environment. Isomorphism's success is evidenced by the ties to Europe and the boost it provides to institutional environments. Thus, the integration with Europe and the momentum it grants to institutional environment is an evidence of success of the Isomorphist strategies. The Europe is replacing the established institutions with a new reference point for Turkey.

Peer-review: Externally peer-reviewed.

Conflict of Interest: The authors have no conflict of interest to declare.

Grant Support: The authors declared that this study has received no financial support.

Author Contributions: Conception/Design of study: XX.; Data Acquisition: XX.; Data Analysis/Interpretation: XX.; Drafting Manuscript: XX.; Critical Revision of Manuscript XX.; Final Approval and Accountability: XX.

\section{References}

Bennan, G. \& Buchanan, J. M. (1985). The reason of rules: constitutional political economy. (The collected works of James M. Buchanan; v. 10). Cambridge, New York: Cambridge University Press.

Berger, P. L. \& Thomas Luckman, T. (1967). The Social construction of reality. New York: Doubleday.

Buchanan, J. M. (2004). The Status of the status quo, Constitutional Political Economy, 15, 133-144.

Cebeci, M. (2016). De-Europeanisation or counter-conduct? Turkey's democratisation and the EU. South European Society and Politics, 21(1), 119-132.

Cohen, M. D., March, J. G. \&. Olsen J. P. (1972). A garbage can model of organizational choice. Administrative Science Quarterly, 17, 1-25.

Çağlar, D. (2007). Human rights conditionality in the relations of the EU and Turkey: a framework for analysis, International Strategic Research Organization, a Research Paper.

Dimaggio, P J. D. \& W. Powell, W. (1983). The iron cage revisited: institutional isomorphism and collective rationality in organizational fields. American Sociological Review, 48(2), 147-160.

Drewry, G. D. (1996). Political institutions: legal perspectives. In R.E.Goodin \& H.D. Klingemann, In A New Handbook of Political Science (pp.191-204). New York: Oxford University Press.

Esen B \& Gümüşçü Ş. (2017). A small yes for presidentialism: the Turkish constitutional referendum of April 2017. South European Society and Politics, 22(3), 303-326,

Festinger, L. (1957). The theory of cognitive dissonance. Stanford, CA: Stanford University Press.

Fischer, H M. \& Pollock, T. G.(2004). Effects of social capital and power on surviving transformational change: the case of initial public offerings. Academy of Management Journal, 47(4), 403-481.

Gambetta, D. (1993). The Sicilian mafia: the business of private protection. Cambridge, MA: Harvard Univ. Pres.

Hannan, Mi T. \& Freeman, J. (1984). Structural inertia and organizational change. American Sociological Review, 49(2), 149-164.

Henisz, W J. \& Zelner, B. A. (2005). Resistance to multilateral influence on reform: the political backlash 
against private infrastructure investments. World Bank Policy Research Working Paper 3690, September.

Hirschman, A. O. (1991). The rhetoric of reaction. Cambridge, MA: Harvard University Press.

Horton, S. (2006). The public service ethos in the British civil service: an historical institutional analysis. Public Policy and Administration, 21(1), 32-48.

Huber, G P. \& Glick, W. H. (1993). Organizational change and redesign, Oxford: Oxford University Press.

Inglehart, R. \& Baker, W.E. (2000). Modernization, cultural change and the persistence of traditional values. American Sociological Review, 65 (February), 19-51.

Julde, D. (2003). Legislative institutionalisation: A bent analytical arrow?. Government and Opposition, 38(3), 497-516.

Kalaycioğlu, E. (2012). Kulturkampf in Turkey: the constitutional referendum of 12 September 2010. South European Society and Politics, 17(1), 1-22.

Klein, P A. \& Miller, E. S. (1996). concepts of value, and democracy in institutional economics. Journal of Economic Issues, 30(1), 267-277.

Krasner, S. (1984). Approaches to the state: alternative conceptions of historical dynamics. Comparative Politics, 16, 223-246.

Lieberman, R. C. (202). Ideas, institutions, and political order: explaining political change. The American Political Science Review, 96(4), 697-712.

Mahoney, J. (2000). Path dependency in historical sociology. Theory and Society, 29, 507-48.

March, J. G. \& Olsen. J. P. (1989). Rediscovering institutions: the organizational basis of politics. New York: Free Press.

North, D. C. (1990). Institutions, institutional change and economic performance. Cambridge: Cambridge University Press.

North, D. C. (2005). Understanding the process of economic change. Princeton, N.J: Princeton University Pres.

Olson, M. (1982). The rise and decline of nations. New Haven and London: Yale University Press.

Özipek, B. B. (2012). Constitution-making in Turkey after the 2011 elections, Turkish Studies, 13(2), 153-167.

Peters, G. (1999). Institutional theory in political science: the new institutionalism. London, New York: Continuum.

Philip M. A. (2013). Cooperative transnationalism in contemporary europe: europeanization and political opportunities for lgbt mobilization in the European Union. European Political Science Review, 5, $279-310$.

Pierson, P. (2000). Increasing returns, path dependence, and the study of politics. American Political Science Review, 94(2), 251-67.

Rodes, R.A.W. (1995). The institutionalist approach, In D. Marsh \& G. Stoker (Eds.), Theory and methods in political science (42-57). London: Macmillan Press.

Rothsteın, B. (1996). Political institutions: An overview. In R. E. Goodin\& H.D. Klingemann (Eds.), A New handbook of political science (133-165), Oxford University Press.

Rowan, B. (1982). Organizational structure and the institutional environment: the case of public schools. Administrative Science Quarterly, 27: 259-279.

Sancar, M \& Eylem Ü. (2007). Yargı1da alg1 ve zihniyet kalıpları. İstanbul: TESEV (Turkish Economic and Social Studies Foundation).

Stinchcombe, A. L. (1995). On the virtues of the old institutionalism. Annual Review of Sociology, 23: 1-18.

Suchman, M.C. (1995). Managing legitimacy: strategic and institutional approaches. Academy of Management Review, 20(3), 571-610.

Thelen, K. (2003). How institutions evolve: insight from comparative historical analysis, in J. Mahoney and D. Rueschemeyer, Comparative historical analysis in the social sciences, Cambridge: Cambridge University Press.

Tool, M R. (1996). A Neo-institutional Theory of Social Change in Veblen's The Theory of the Leisure Class. Presented at Meetings of the European Association for Evolutionary Political Economy. Krakow, Poland, October 1995, and at meetings of the International Thorstein Veblen Association at Carleton College in Northfield MN, May 1.

Weir, M. (1995). Ideas and the politics of bounded innovation, in S. Steinmo, K. Thelen \& Longstreth, F. (Eds), Structuring Politics: Historical Institutionalism in Comparative Analysis, Cambridge: Cambridge University Press.

Williamson, O. (1975). Markets and hierarchies. New York: Free Press and London: Collier Macmillan.

Zeynep Y. (2017). Oppositional usages of Europeanization in Turkish constitution-making: discussions on religious freedom. Turkish Studies, 18(4), 644-664.

Zucker, L. G. (1977). The Role of institutionalization in cultural persistence. American Sociological Review, 42, 726-743.

structure. 
